\title{
HEAT ILLNESS IN ENGLAND
}

\author{
Lieutenant-Colonel J. CARSON, M.B., M.R.C.P., D.T.M\&H., R.A.M.C. * \\ Colonel J. F. WEBB, M.C., M.D., F.R.C.P.,(Ed.), Late R.A.M.C. \\ Cambridge Military Hospital, Aldershot
}

\begin{abstract}
SUMMARY: There is a tendency to under-estimate the significance of heat illness in the United Kingdom (U:K.) despite the fact that cases are known to occur during military training (Manual of Army Health 1965). Manson-Bahr (1966) states that it has a restricted geographical distribution and does not mention U.K. in his list of endemic areas. Many patients are seen in the Aldershot area each year suffering from heat illness and some are admitted to hospital and this paper describes 14 selected cases who required admission during the period 1969-1971 inclusive.
\end{abstract}

The cause of admission in the patients described was disturbance of consciousness ranging from confusion and drowsiness to profound coma.

\section{Clinical histories}

Case 1. Admitted on 25 June 1969. A 24 year old officer cadet who had had little exercise for one month, and a coryza four days earlier, collapsed after running 9.5 miles in battle order. He was initially comatose, sweating profusely, and vomited. $\mathrm{He}$ was sponged with tepid water and two pints of rectal saline were given during transfer to hospital. On arrival two hours later his oral temperature was $102^{\circ} \mathrm{F}\left(39.9^{\circ} \mathrm{C}\right)$ and he was profusely incontinent of faeces. He made a rapid and complete recovery.

Case 2. Admitted on 30 June 1969. A 17 year old recruit who had done physical training that morning, collapsed after running three to four miles in vest, slacks and boots in the afternoon. He was drowsy and confused on admission but his oral temperature was only $99.4^{\circ} \mathrm{F}\left(37.4^{\circ} \mathrm{C}\right)$ and rapid recovery followed.

Case 3. Admitted on 30 June 1969. An 18 year old recruit collapsed shortly after Case 2 in the same circumstances. He was sweating, comatose, and had an axillary temperature of $105^{\circ} \mathrm{F}\left(40.6^{\circ} \mathrm{C}\right)$. Tepid sponging was given during transport to hospital. $\mathrm{He}$ was comatose on arrival and profusely incontinent of faeces. Rectal temperature was $105^{\circ} \mathrm{F}\left(40.6^{\circ} \mathrm{C}\right)$. Active cooling, intravenous fluids and chlorpromazine were given, and he regained consciousness that evening. There was albuminuria and a transiently raised blood urea, followed by jaundice and a raised transaminase on the fourth day. He was anicteric and well by the seventh day.

Case 4. Admitted on 30 June 1969. A 23 year old recruit collapsed at the end of the eight mile run being attempted by the last two patients. He was brought immediately to hospital where he was comatose, had vomited, and was incontinent of faeces. Rectal temperature was $104.6^{\circ} \mathrm{F}\left(40.3^{\circ} \mathrm{C}\right)$ and his blood pressure was low. He had similar biochemical abnormalities to Case 3 together with haematuria and received similar treatment. He was discharged well on the tenth day.

Case 5. Admitted on 1 July 1969. An 18 year old officer cadet who collapsed at the end of an eight mile run. He was very drowsy with hot dry skin and an oral temperature of $102^{\circ} \mathrm{F}\left(38.9^{\circ} \mathrm{C}\right)$. Rapid recovery followed rest and intravenous fluids.

* Now Military Hospital, Tidworth. 
Case 6. Admitted on 1 July $19699^{\circ}$ A second 18 year old officer cadet who also collapsed at the end of an eight mile run. He was reported to have felt weak and dizzy but to have pressed on to the end. He was initially drowsy and sweating profusely but rapidly improved with intravenous fluids.

Case 7. Admitted on 2 July 1969. A 17 year old soldier admitted to another hospital on 1 July 1969 having collapsed on a ten mile march. He was described as delirious, with profuse diarrhoea, vomiting and sweating. "Presumably due to severe gastroenteritis ". He was treated with intravenous fluids and was well on arrival at this hospital.

Case 8. Admitted on 22 July 1969. This 21 year old soldier had returned to the parachute brigade after doing a clerical job in Germany. He collapsed on his second training run. He was confused, sweating and vomited, but his oral temperature was only $99.8^{\circ} \mathrm{F}$ $\left(37.7^{\circ} \mathrm{C}\right)$ and he recovered rapidly with oral fluids.

Case 9. Admitted on 16 August 1969. A 17 year old recruit who collapsed after running 6 miles. He was confused, rambling and sweating, with an oral temperature of $104.4^{\circ} \mathrm{F}\left(40.2^{\circ} \mathrm{C}\right)$. After tepid sponging and oral fluids, he made a rapid recovery.

Case 10. Admitted on 24 June 1971. A 20 year old officer cadet from Thailand collapsed at the end of a ten mile run, having felt ill for the last 2 or 3 miles. He was deeply comatose and profusely incontinent of faeces. Rectal temperature was $107.8^{\circ} \mathrm{F}$ $\left(42.1^{\circ} \mathrm{C}\right)$ and his blood pressure was low.

Active cooling, intravenous fluids, and chlorpromazine were given, and he regained consciousness the following morning. There was albuminuria and casts in the urine and he later developed jaundice and had a brief epistaxis. Serum transaminases and blood urea were raised but clotting factors were not studied. He made a complete recovery and was discharged on the tenth day.

Case 11. Admitted on 22 June 1971. An 18 year old recruit who had felt unwell after marching 8 miles in full kit, but continued to complete 10 miles when he collapsed. He was subsequently given a tepid bath and rested for some time, but still feeling weak and unsteady was brought to hospital. An initial oral temperature of $103^{\circ} \mathrm{F}\left(39.4^{\circ} \mathrm{C}\right)$ was recorded which thereafter fell to normal. He rapidly became comatose and incontinent, developed hypertension and a left hemiplegia and had haematuria. The renal lesion progressed to acute tubular necrosis and hypotensive therapy and peritoneal dialysis were necessary. He made a near complete recovery with a residual weakness and clumsiness of left hand.

This case had been described in detail elsewhere (Carson and Webb 1972).

Case 12. Admitted on 3 August 1971. A 19. year old subaltern on a parachute training course collapsed at the end of afternoon training and was brought directly to hospital. He was confused, restless, sweating and had profuse diarrhoea. Rectal temperature was $104.4^{\circ} \mathrm{F}\left(40.2^{\circ} \mathrm{C}\right)$. He made a complete recovery after intravenous fluids and a brief period of active cooling.

Case 13. Admitted on 3 August 1971. A 19 year old commando on parachute training collapsed after running 7 miles. On arrival in hospital he was irritable and confused, sweating profusely and had a rectal temperature of $106^{\circ} \mathrm{F}\left(40.6^{\circ} \mathrm{C}\right.$.) Treated by active cooling with intravenous fluids and chlorpromazine he made a rapid and uneventful recovery. 
Case 14. Admitted on 10 December 1971. A 22 year old recruit collapsed in midafternoon after running 6 miles in full kit. He had not slept well for the previous two nights and had been physically active all day, but had taken little to drink.

He was drowsy and rambling on arrival in hospital, and his rectal temperature was $105^{\circ} \mathrm{F}\left(40.4^{\circ} \mathrm{C}\right)$. He responded to tepid sponging and oral fluids. He had albuminuria and a blood urea of $64 \mathrm{mg} / 100 \mathrm{ml}$ on the second day. He remained anicteric and was physically well, but an SGPT of 575 I.U. was recorded on the fourth day, by which time the blood urea was normal.

Predisposing factors

\section{Results}

Table I lists the factors considered relevant in this series, and Table II the average monthly maximum temperatures in the relevant months of 1969,1970 and 1971.

Table I

Predisposing factors in heat illness

\begin{tabular}{|c|c|c|c|c|}
\hline Case & Status & $\begin{array}{l}\text { Daily maximum } \\
\text { temperature }\left({ }^{\circ} \mathrm{C}\right)\end{array}$ & $\begin{array}{l}\text { Immediate } \\
\text { situation }\end{array}$ & $\begin{array}{l}\text { Other known } \\
\text { relevant factors }\end{array}$ \\
\hline 1 & Officer cadet & 20.5 & Running $9 \frac{1}{2} \mathrm{~m}$ & $\begin{array}{l}\text { a. Coryza. b. Little } \\
\text { exercise recently. }\end{array}$ \\
\hline 2 & $\begin{array}{l}\text { Recruit } \\
\text { Parachute Regiment }\end{array}$ & 24.7 & Running $4 \mathrm{~m}$ & - \\
\hline 3 & $\begin{array}{l}\text { Recruit } \\
\text { Parachute Regiment }\end{array}$ & 24.7 & Running $4 \mathrm{~m}$ & - \\
\hline 4 & $\begin{array}{l}\text { Recruit } \\
\text { Parachute Regiment }\end{array}$ & 24.7 & Running $8 \mathrm{~m}$ & - \\
\hline 5 & Officer cadet & 25.3 & Running $8 \mathrm{~m}$ & - \\
\hline 6 & Officer cadet & 25.3 & Running $8 \mathrm{~m}$ & - \\
\hline 7 & $\begin{array}{l}\text { Recruit } \\
\text { Parachute Regiment }\end{array}$ & 22.6 & Marching $10 \mathrm{~m}$ & - \\
\hline 8 & $\begin{array}{l}\text { Re-training } \\
\text { Parachute Brigade }\end{array}$ & 25.5 & Running ? $\mathrm{m}$ & $\begin{array}{l}\text { Just returned to Brigade } \\
\text { from sedentary job. }\end{array}$ \\
\hline 9 & $\begin{array}{l}\text { Recruit } \\
\text { Parachute Regiment }\end{array}$ & 22.9 & Running $6 \mathrm{~m}$ & - \\
\hline 10 & Officer cadet & 22.5 & Running $10 \mathrm{~m}$ & $\begin{array}{l}\text { Unwell for last } 2 \text { to } \\
3 \text { miles. }\end{array}$ \\
\hline 11 & $\begin{array}{l}\text { Recruit } \\
\text { Royal Engineers }\end{array}$ & 16.6 & Marching $10 \mathrm{~m}$ & $\begin{array}{l}\text { Collapsed-encouraged } \\
\text { to continue. }\end{array}$ \\
\hline 12 & $\begin{array}{l}\text { Officer } \\
\text { Parachute Regiment }\end{array}$ & 21.5 & $\begin{array}{l}\text { Collapse at end } \\
\text { of a day of } \\
\text { physical activity }\end{array}$ & $\begin{array}{l}\text { Newly commissioned } \\
\text { into regiment. }\end{array}$ \\
\hline 13 & $\begin{array}{l}\text { Commando } \\
\text { Attached Parachute Brigade }\end{array}$ & 21.5 & Running $7 \mathrm{~m}$ & $\begin{array}{l}\text { Had felt unwell, "but didn't } \\
\text { give up because he was a } \\
\text { marine!". }\end{array}$ \\
\hline 14 & $\begin{array}{l}\text { Recruit } \\
\text { Parachute Regiment }\end{array}$ & 10.2 & Running $6 \mathrm{~m}$ & $\begin{array}{l}\text { a. Disturbed sleep for } 2 \\
\text { nights. b. Felt thirsty. } \\
\text { c. Age } 23 \text { but previous } \\
\text { TAVR training and wanted } \\
\text { 'to show he could do it'. }\end{array}$ \\
\hline
\end{tabular}


Table II

Average monthly maximum temperatures (degrees centigrade)

\begin{tabular}{l|r|r|r}
\hline \multirow{2}{*}{ Month } & \multicolumn{3}{|c}{ Year } \\
\cline { 2 - 4 } & 1969 & 1970 & 1971 \\
\hline June & 19.8 & 23.0 & 17.0 \\
July & 23.0 & 20.7 & 23.3 \\
August & -21.3 & - & 9.4 \\
December & & & \\
\hline
\end{tabular}

All but one case occurred in the summer months, and twelve occurred on days when the daily maximum temperature exceeded the average monthly maximum temperature. Case 14 occurred on a colder day, but still hotter than the monthly average. In this case however, additional factors were particularly important. All cases occurred after sustained physical effort, and continued effort despite the desire to rest was noted in several patients.

\section{Premonitory symptoms}

Weakness, dizziness, malaise and blurred vision were the main premonitory symptoms noted.

\section{Clinical and biochemical findings}

The clinical and biochemical findings are summarised in Table III. Five patients were comatose on arrival in hospital and sweating was noted in nine patients, including two with heat stroke. Diarrhoea and faecal incontinence occurred frequently. The blood pressure was generally normal although some patients had transient hypotension. Albuminuria was a constant finding.

Confusion on recovery from coma, and slight aggressive tendencies were noted in several patients; and as noted one patient developed a left hemiplegia.

Biochemical findings were not helpful initially, although subsequent elevation of serum enzymes is necessary to confirm a diagnosis of heat stroke. Thus the serum glutamic oxaloacetic transaminase (SGOT) was raised in four cases, three of which were also icteric, and in one case the serum glutamic pyruvate transaminase was raised. Blood urea estimations tended to show high figures initially and repeat estimations in those more severely affected showed a rise despite a fall in temperature and rehydration. This rise was usually more marked when the initial blood urea was raised, and was particularly so in the patient who developed renal failure.

Electrolyte estimations were inıportant in controlling therapy, but were of no diagnostic value initially. Haematological results were unhelpful but the importance of excluding malaria needs emphasis (Hargreaves and Morrison 1965).

\section{Treatment}

The principles employed in treatment were active cooling by promoting evaporation of tepid water from a closely applied sheet with the aid of fans and in some patients ice was placed in the axillae or groins but we are aware of the possibility that liberai use of 
Table III

Clinical and biochemical findings

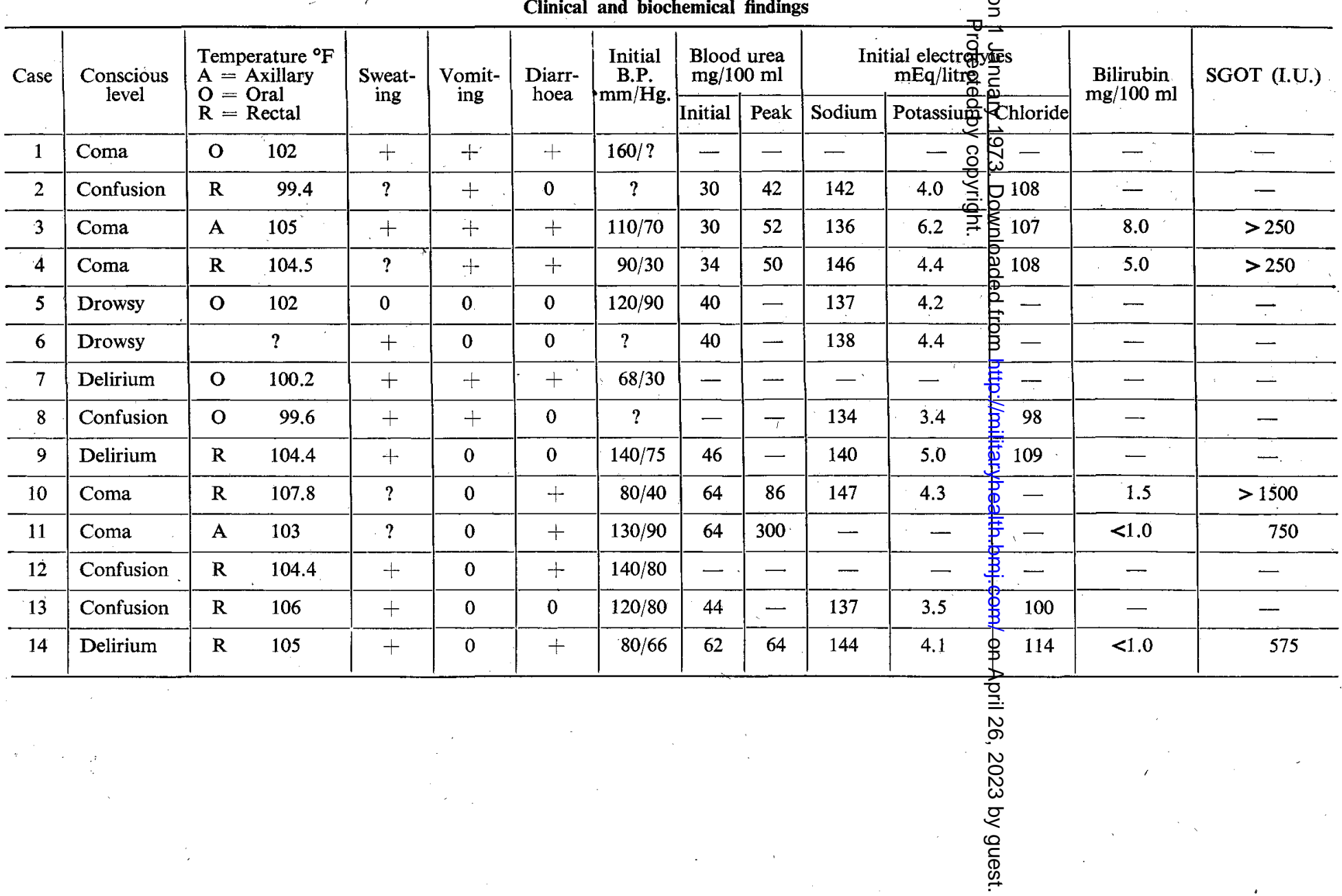


ice may be self defeating by promoting vasco-constriction. In 1971, the rectal temperature was constantly monitored during cooling using a probe and meter (Electrolaboratoriet - Copenhagen). Cooling was stopped when the rectal temperature fell to $102^{\circ} \mathrm{F}$, and no cases required further active cooling. Chlorpromazine 25 to $50 \mathrm{mg}$ was given intramuscularly if shivering occurred during cooling (Cases 3, 4, 10 and 13).

In four cases rapid recovery allowed adequate replacement of fluid loss orally using squashes and milk, but not plain water, and no cases of cramp occurred. All other patients were given intravenous fluids; usually normal saline. The quantity given varied from two to four litres over the first twelve to eighteen hours.

\section{Outcome}

All patients survived, the majority with brief hospitalisation only. Patients 3,4 , 10,11 and 14, were considered to have suffered heat stroke. Four recovered completely and left hospital between the sixth and fifteenth day. Case eleven developed acute renal failure, a left hemiplegia, hypertension and myocardial damage. He was left with residual neurological disability, but renal function appeared normal six months after the acute event.

\section{Classification of heat illness}

\section{Discussion}

Heat stroke is defined as a disturbance of consciousness due to a body temperature of $105^{\circ} \mathrm{F}\left(40.6^{\circ} \mathrm{C}\right)$ or higher (Leithead 1965$)$. Such patients will almost always have raised serum enzymes (Shibolet et al 1967). We consider cases 3, 4, 10, 11 and 14 to have had heat stroke, all five of which had raised serum enzymes, although two did not have the above mentioned elevation of temperature. All other cases would be defined as salt and water deficiency, in which moderate elevation of body temperature may occur. We deliberately excluded patients presenting with "Heat cramp", the third type of heat illness likely to occur in this country.

\section{Significance of recorded temperature}

We feel that the recorded temperature may give a wrong impression unless considered in the context of the overall situation. There are three reasons for this. First, in a temperate climate, the rate of heat production will fall rapidly once exercise ceases, that is, when the patient collapses. Here the time factor is important. Second, cooling may be brought about deliberately, as by fanning, sponging, and spraying with water, or incidentally, as by transporting in a draughty vehicle, before the patient reaches a hospital or medical centre. (This is illustrated by Case 3 whose axillary temperature of $105^{\circ} \mathrm{F}$ apparently fell to $102^{\circ} \mathrm{F}$ with sponging, but on arrival in hospital his rectal temperature was $105^{\circ} \mathrm{F}$ ). Third, only the rectal temperature should be accepted as reliably reflecting the "core" temperature.

\section{Clinical picture}

In a hospital accepting patients from a number of training centres, it is noteworthy that with one exception, all the patients were either officer cadets, or training with the parachute brigade. They are comparable to patients observed by Shibolet et al (1967) who described 36 cases of heat stroke occurring in young men in Israel, and observed that it strikes the highly motivated under discipline of work, military training, or sporting endeavour. 
The characteristic history is thus one of sustained physical exertion with a group carried out as a rule in relatively high environmental temperatures. Exertion is noted to continue despite "Malaise" in many cases. Factors also known to be associated with heat illness such as poor health, fatigue, alcohol intake and water deprivation are important but are only of major significance in case 14 of our series.

Our patients presented with disturbed consciousness and varying temperatures, and in view of the comments already made about the level of pyrexia, it may be difficult to classify the two types of illness we describe. We feel that there is probably some overlap between them, and the problem may be to distinguish heat illness from other causes of coma. We consider heat illness is the most likely diagnosis when a previously fit young man is admitted with coma, fever, and profuse faecal incontinence, together with a history of having collapsed during sustained exertion.

In the past the presence or absence of sweating has been used to differentiate between heat stroke (anhydrotic) and salt and water depletion illness. This distinction is possibly of value in the tropics where disorders of sweat loss may precede heat stroke. It has been recognised for a long time however that heat stroke patients may sweat (Malamud, Haymaker and Custer 1946), and the great majority of cases described by Shibolet et al (1967), were also sweating.

In our series the majority of patients were sweating, as should be expected in salt and water depletion, but two cases of heat stroke were also definitely sweating. Case eleven was seen late, but Cases 4 and 10 were both being cooled when seen by one of us, and no record of sweating had been made. Nevertheless we felt that the Israeli experience is more akin to what may occur in this country.

\section{Course of heat stroke}

Cases of salt and water depletion may be expected to recover rapidly with rehydration and this was indeed the case. The following remarks therefore apply to patients with heat stroke.

No patients developed convulsions, their occurrence indicating more severe damage as a rule, and in all cases "the temperature fell satisfactorily with cooling without significant rebound.

Generalised tissue damage occurs in heat stroke, and elevation of blood enzyme levels almost invariably occurs (Shibolet et al 1967).

Renal involvement occurs in almost all cases, and renal tubular necrosis may occur. (Kew et al 1967). Such involvement is manifested by albuminuria, red cells and casts in the urine, and by a rise in the blood urea level despite adequate rehydration.

Evidence suggesting liver damage was seen in Cases 3,4 and 10 and is also one of the commonest manifestations of this condition (Malamud, Haymaker and Custer 1946). There may also be a fall in prothrombin and fibrinogen levels, and also of other clotting factors such as pro-accelerin and proconvertin, and thrombocytopenia, leading to abnormalities of clotting tests, or frank bleeding.

This bleeding tendency may contribute to the neurological complications sometimes seen. Transient irritability has been noted, as in our patients, but permanent sequelae such as the paresis and astereognosis experienced by case eleven are recognised. Post mortem studies have shown widespread petechiae in the brain and meninges, sometimes with more gross haemorrhages. 
Transient cardiovascular abnormalities occur. There is probably a tendency to hypotension at the onset of the illness and its persistence indicates a poor prognosis (Shibolet et al 1967). One of our patients developed hypertension in association with renal failure, and this complication is also described when there is evidence of raised intra-cranial pressure, or sometimes with no apparent cause. Myocardial petechiae and necrosis have been recorded at post mortem. A deep $Q$ wave in lead III in Case eleven may represent an area of necrosis although E.C.G. abnormalities other than sinus tachycardia are probably rare.

\section{Treatment}

Fluid replacement is important as dehydration is the rule. This will usually be given intravenously using normal saline and dextrose saline and monitoring the electrolytes. We did not note hypokalaemia in our patients, although this is recognised and may be associated with the frequently noted diarrhoea, or possibly related to increased salt intake during periods of acclimatisation (Knochel and Vertel 1967).

Cooling is required if the rectal temperature is greater than $40.6^{\circ} \mathrm{C}$ and is best achieved by sponging or wrapping the patient in a closely applied wet cotton sheet. In both cases evaporation is assisted by fanning. The temperature must be monitored by frequent rectal recordings, and we have found an indwelling electrode invaluable. Overcooling is avoided by stopping active cooling at $102^{\circ} \mathrm{F}\left(38.8^{\circ} \mathrm{C}\right)$. We used chlorpromazine $25-50 \mathrm{mg}$, intramuscularly to prevent further heat production by shivering, although others have used pethidine and promethazine.

It is our experience that ice has almost always been sent for or is in use when we see a patient. Although this is a traditional treatment it is unnecessary, and may in fact be harmful by producing local vasoconstriction and impaired heat loss.

\section{Prevention}

There appears to be a very strong personal element in the cases seen latterly, in that the individual felt unwell, but for reasons of personal or group pride continued his exertions. This also applied to Case 14, although other recognised factors were present.

Assuming that men are previously fit, the occurrence of weakness, malaise, odd behaviour, or unsteadiness, should be taken as danger signals, and we feel that such men should not be encouraged to continue exertion without adequate rest and rehydration. Indeed in highly motivated soldiers as in the case of the patients described such symptoms must be looked for by supervising officers.

It is recognised however that the majority of cases probably occur without other than subjective warning (Malamud, Haymaker and Custer 1946).

\section{Conclusion}

Sustained physical effort in otherwise fit young soldiers in a temperate climate may lead to rising body temperature and dehydration, especially during the summer months. In these circumstances "collapse" with disturbed consciousness may occur either suddenly, or following a period of malaise which would perhaps have caused less well motivated men to rest.

In the majority of cases the most significant factor in this collapse is salt and water deficiency, and rapid recovery follows fluid and electrolyte replacement. In a significant 
minority however, hyperpyrexia at the time of collapse is more significant. These patients have heat stroke and require immediate cooling, preferably during transfer to hospital, where continued cooling and rehydration are carried out. They should subsequently be monitored for evidence of generalised tissue damage.

Prevention may be difficult, as the condition appears to occur in particularly fit individuals who persist in exertion despite subjective malaise. Factors such as sleep loss, alcohol, and dehydration are to be avoided, and no individual who falls out with vague malaise should continue without adequate rest and rehydration.

\section{Acknowledgements}

We wish to thank Dr. H. A. Lee, B.Sc., M.D., M.R.C.P., Director of the Renal Unit, St. Mary's Hospital, Portsmouth for his helpful comments in the preparation of this paper, and Mr. J. J. Allen, Senior Meteorological Officer, Royal Aircraft Establishment, Farnborough for the meteorological data.

\section{REFERENCES}

Carson, J, and Webb, J. F. (1972). Proc. roy. Soc. Med. 65, 752.

Hargreaves, W. H. and Morrison, R. J. G. (1965). The Practice of Tropical Medicine. p. 373, Staples Press, London.

Kew, M. C., Abrahams, C., Levin, N. W., Seftel, H. C., Rubenstein, A. H. and Bersohn, I, (1967). Quart. J. Med. 36, 277.

KNOCHEL, J. P. and VERTEL, R. M. (1967). Lancet i, 659.

Leithead, C. S. (1965). In Exploration Medicine. John Wright \& Sons Ltd. Bristol.

Malamud, N., Haymaker, W. and Custer, R. P. (1946). Milit. Surg, 99, 397.

Manson-BAhr, Sir P. H. (1966). Mansons Tropical Diseases. 16th ed. p. 341. Cassell \& Co. Ltd. London. Manual of Army Health (1965). P. 41. H.M.S.O. London.

Shibolet, S., Coll., R., Gilat, T. and Sohar, E. (1967). Quart. J. Med, 36, 525.

Colonel Commandant R.A.D.C.

Brigadier R. H. Green, M.B.E., L.D.S., R.C.S., has been appointed Colonel Commandant R.A.D.C., with effect from 24 April 1973. 